\title{
PEMANFAATAN LIMBAH ORGANIK SEBAGAI MEDIA PAKAN Tenebrio molitor
}

\author{
Ica Veronika Maha ${ }^{1}$, Elfrida ${ }^{2}$, Tri Mustika Sarjani ${ }^{3}$ \\ Pendidikan Biologi, Fakultas Keguruan dan Ilmu Pendidikan, Universitas Samudra \\ Email: icaveronikamaha@gmail.com
}

\begin{abstract}
ABSTRAK
Penelitian ini bertujuan untuk mengetahui konsumsi limbah organik yang paling optimal sebagai media pakan Tenebrio molitor. Penelitian ini menggunakan pendekatan kuantitatif dan jenis penelitian eksperimen dengan Rancanga Acak Lengkap (RAL) terdri dari 3 perlakuan dan 6 pengulangan yaitu, P1 (limbah sayur), P2 (limbah ikan), P3 (limbah sayur+limbah ikan). Parameter penelitian menggunakan mortalitas larva, konsumsi larva Tenebrio molitor pertambahan bobot tubuh larva. Data dianalisis menggunakan uji Anova Dua Jalur (two way) dan uji lanjut Jarak Nyata Duncan dengan taraf kepercayaan 0,05. Hasil dari penelitian menunjukkan bahwa konsumsi larva pada pakan limbah berpengaruh dan saling berinteraksi dengan umur larva. Hal ini menunjukkan $F_{\text {hitung }}(6,52)>F_{\text {tabel }}(2,10)$. Pakan paling optimal sebagai media pakan Tenebrio molitor adalah P3 (limbah sayur+limbah ikan) karena memiliki rerata konsumsi makan tertinggi dengan tingkat mortalitas hanya mencapai 47\%. Pertambahan bobot tubuh yang konsisten selalu meningkat dan tertinggi di bandingkan perlakuan yang lain.
\end{abstract}

Kata kunci : Tenebrio molitor, Limbah Organik, Mortalitas, Konsumsi, Larva

\begin{abstract}
This study aims to determine the optimal organic waste feed as a feed medium for Tenebrio molitor. The approach to research is a quantitative approach. This type of experimental research with a Rancangan Acak Lengkap (RAL) consisting of 3 treatments and 6 repetitions was used to study Tenebrio molitor larvae P1 (vegetable waste), P2 (fish waste), P3 (vegetable waste + fish waste). Parameters in this study were larval mortality, consumption of Tenebrio molitor larvae, larval body weight gain. The data were analyzed using the Two-way ANOVA test and Duncan's Advanced Real Distance test at a significant level of 0.05 . The results showed that the consumption of larvae in the waste feed influenced and interacted with the age of the larvae. This shows Fount $(6,52)>F$ table $(2,10)$. From the results of the study, it can be concluded that the most optimal feed as a feed medium for Tenebrio molitor is P3 (vegetable waste + fish waste) because it has the highest average food consumption with a mortality rate of only $47 \%$. Consistent body weight gain always increases and is the highest compared to other treatments.
\end{abstract}

Keywords: Tenebrio molitor, Organic Waste, Mortality, Consumption, Larvae 


\section{PENDAHULUAN}

Data Kementerian Lingkungan Hidup dan Kehutanan (2020) menunjukkan volume sampah Indonesia pada tahun 2017 meningkat menjadi 65,8 juta ton dan pada tahun 2020 meningkat menjadi 67,8 juta ton. Komposisi sampah didominasi oleh limbah organik yakni mencapai $60 \%$ dari total keseluruhan sampah. Limbah jenis ini banyak dihasilkan dari konsumsi masyarakat seperti pasar tradisional dan kalangan rumah tangga setiap hari dengan jumlah yang besar. Limbah organik biasanya seperti sisa-sisa sayuran dan jeroan ikan. Biasanya limbah dibuang secara sengaja di jalan, sungai dan ditumpuk begitu saja di TPA (tempat pembuangan akhir) yang membahayakan kesehatan masyarakat dan merusak keindahan lingkungan.

Limbah sayur dan limbah jeroan ikan mempunyai banyak kandungan nutrisi untuk dijadikan sebagai pakan ternak. Kandunga dari limbah sayur memiliki protein kasar 12,64-23,50\% dan kandungan serat kasar mencapai 20,7629,18\% (Santoso, 2015). Sedangkan limbah jeroan ikan mengandung kandungan protein sebesar $32 \%$, kalsium $4 \%$ dan fosfor 3\% (Adawiyah, 2014). Limbah sayuran dan limbah jeroan ikan yang sering terbuang memiliki kandungan gizi yang tinggi yang cocok untuk sebagai pakan ternak yang meningkatkan pertumbuhan seperti Tenebrio molitor.

Tenebrio molitor adalah hewan kelas insekta biasanya sebagian besar hidupnya melalui fase larva. Larva Tenebrio molitor yang sangat membutuhkan banyak makan untuk proses pertumbuhan tubuh hingga larva mencapai fase moulting (pupa). Larva Tenebrio molitor merupakan omnivora dan dapat memakan semua jenis bahan tanaman serta produk hewan seperti daging dan bulu. Tenebrio molitor sangat mudah dibudidayakan sehingga dapat dimanfaatkan menjadi pakan ternak karena diyakini memiliki kandungan gizi yang tinggi cocok untuk dijadikan makanan ternak. Kandungan protein Tenebrio molitor mencapai 48\%, lemak kasar $40 \%$, kadar abu 3\%, ekstrak nitrogen $8 \%$ dan kadar air 57\% (Finke, 2004). Sehingga kandungan protein terdapat didalam tubuh Tenebrio molitor menjadi salah satu pakan alternatif yang sangat efektif untuk diberikan pada jenis unggas pemakan serangga, ikan dan reptil.

\section{METODE PENELITIAN}

\section{Alat dan Bahan}

Bahan yang digunakan untuk penelitian ini yaitu ulat hongkong berumur 15 hari setelah telur menetas sebanyak 1500 ekor, limbah sayur dan limbah ikan yang didapat dari pasar. Peralatan yang 
digunakan selama peneltian adalah kotak plastik berukuran $20 \mathrm{~cm} \times 10 \mathrm{~cm} \times 5 \mathrm{~cm}$ dan timbangan analitik.

\section{Rancangan Penelitian}

Penelitian menggunkana metode eksperimen dengan model rancangan penelitian RAL (Racangan Acak Lengkap) mengunakan 3 perlakuan dan 6 pengulangan. Perlakuan yang digunakan sebagai berikut: Perlakuan 1 (P1): pakan limbah sayuran, Perlakuan 2 (P2): pakan limbah ikan, Perlakuan 3 (P3): pakan campuran limbah ikan dan limbah sayuran.

\section{Prosedur penelitian}

\section{Persiapan kotak budidaya}

Kotak budidaya akan dipindahkan susunannya agar suhu yang ada tetap stabil (tidak terlalu panas dan tidak terlalu lembab) dan melakukan pembersihan kandang secara rutin. Bagian atas kotak budidaya ditutupi dengan kain jaring (kelambu) untuk menutupi area kandang. Fungsi kain jaring sebagai penghalang lalat atau serangga kecil yang ingin masuk ke dalam area kandang (Purnamasari, 2018).

\section{Persiapan media pakan}

Media pakan yang digunakan dalam penelitian adalah limbah ikan dan limbah sayur masing-masing diberi 20 gram setiap perlakuan/hari. Sebelum pemberian pada larva dan pencampuran media pakan ada baiknya limbah ikan dikukus terlebih dahulu.

\section{Persiapan larva Tenebrio molitor}

Tahap persiapan dimulai dari memasukkan pakan limbah ikan, limbah sayur dan campuran limbah sayur+ikan. Sebelumnya, masing-masing ketiga jenis pakan limbah tersebut ditimbang sebanyak 20 gram. Kemudian melakukan penimbangan bobot tubuh diawal pada larva Tenebrio molitor. Sampel larva Tenebrio molitor diambil masing-masing 500 ekor untuk setiap perlakuan. Pemberian pakan limbah dilakukan setiap hari serta melakukan penimbangan pakan sebelum dan sesudah pemberian kepada larva. Setiap rentang 10 hari pemeliharaan larva Tenebrio molitor melakukan penimbangangan bobot tubuh serta menghitungan jumlah mortalitas pada larva.

\section{Variabel yang diamati}

\section{Mortalitas}

Mortalitas larva pada setiap perlakuan berbeda-beda, dapat diketahui dengan cara menghitung jumlah larva yang masih hidup mengunakan rumus:

Mortalitas $=($ jumlah larva mati $:$ jumlah larva awal) x $100 \%$ 


\section{Konsumsi larva}

Penimbangan berat kosumsi yaitu jumlah limbah sisa yang telah dikonsumsi larva Tenebrio molitor yang dilakukan setiap hari. adapun rumus yang digunakan sebagai berikut:

konsumsi (mg/ekor/ hari) = (berat di awal - berat di akhir $)$

\section{Pertambahan berat tubuh larva}

Pengukuran berat tubuh dilakukan setiap 10 hari sekali. Adapun rumus digunakan sebagai berikut:
Pertambahan tubuh (mg/ekor) = (berat diakhir-berat diawal)

\section{Analisis Data}

Data yang didapat hasil penelitian diolah dengan program SPSS dan dianalisis menggunakan analisis varian (ANOVA) dari rancangan acak lengkap pola faktorial. Apabila menunjukkan perbedaan pengaruh diantara perlakuan maka di lanjutkan dengan uji jarak berganda duncan's.

\section{HASIL DAN PEMBAHASAN}

\section{Mortalitas Larva Tenebrio molitor}

Adapun hasil mortalitas larva dapat dilihat pada gambar. 1 Mortalitas Larva Tenebrio molitor sebagai berikut :

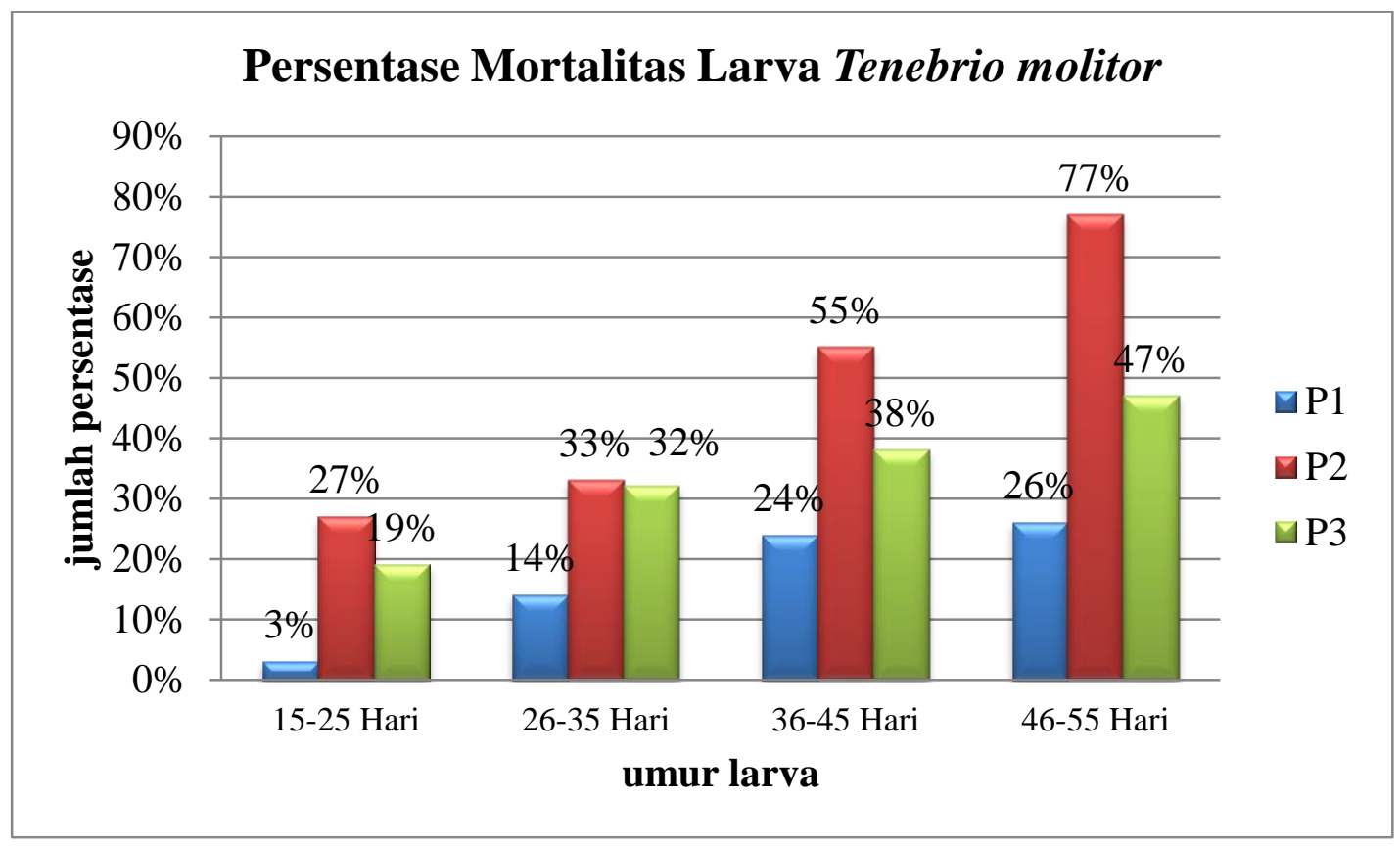

Gambar 1. Mortalitas Larva Tenebrio molitor

Keterangan: P1 (limbah sayur), P2 (limbah ikan) dan P3 (limbah sayur+limbah ikan)

Namun, tingkat resiko kematian dapat dilihat tabel mortalitas larva halaman pada P2 (limbah ikan) sangat tinggi juga 50, jumlah persentase kematian larva pada 
P2 (limbah ikan) di umur 36-45 hari mencapai 55\% dengan jumlah 275 ekor mengalami kematian dari 500 ekor. Hal ini dikarenakan, pakan limbah ikan cenderung lebih cepat mengalami kebusukan dibandingkan limbah sayur yang disebabkan kadar air yang tinggi sangat mempengaruhi daya makan larva itu sendiri. Menurut Tumando (2017) menyatakan air merupakan kandungan yang terbesar dalam ikan sehingga mengakibatkan sarana mikroorganisme untuk berkembang. Pembusukan sampah terjadi akibat perubahan pada media pakan, dimana media pakan cenderung berair di bagian bawah yang berakibat larva bergerak menuju ke permukaan media pakan. Banyaknya air di dalam media pakan dapat berpengaruh tingkat mortalitas dari larva (Azizah, 2019:296).

\section{Konsumsi Larva Tenebrio molitor}

Adapun hasil Kosumsi larva dapat dilihat pada tabel 1. Konsumsi Larva Tenebrio molitor sebagai berikut :

Tabel 1. Konsumsi Larva Tenebrio molitor

\begin{tabular}{lccccc}
\hline Pelakuan & \multicolumn{4}{c}{ Umur (hari ke-) } & Rerata \pm SD \\
\cline { 2 - 5 } & \multicolumn{1}{c}{$15-25$} & $26-35$ & $36-45$ & $46-55$ \\
\cline { 2 - 5 } & \multicolumn{4}{c}{ mg/ekor/hari } \\
\hline P1 (Limbah sayur) & $3,03 \pm 2,18$ & $12,86 \pm 2,76$ & $32,39 \pm 1,99$ & $41,17 \pm 4,07$ & $22,37 \pm 15,72^{\mathrm{a}}$ \\
\hline P2 (Limbah ikan) & $3,60 \pm 2,18$ & $17,63 \pm 3,75$ & $41,04 \pm 2,10$ & $54,49 \pm 12,07$ & $29,12 \pm 21,12^{\mathrm{b}}$ \\
\hline P3 (Limbah sayur dan ikan) & $5,64 \pm 1,74$ & $13,17 \pm 3,42$ & $36,45 \pm 4,09$ & $60,38 \pm 2,38$ & $28,91 \pm 22,07^{\mathrm{b}}$ \\
\hline
\end{tabular}

Keterangan:

Superscript huruf yang berbeda menunjukkan berbeda pada taraf signifikan $\alpha=0,05$

Pakan limbah organik memiliki

tambahan. Laju konsumsi larva keunggulan untuk dijadikan konsumsi dipengaruhi dengan ketersediaan nutrisi larva Tenebrio molitor. Konsumsi umur larva 15-25 hari yang tertinggi yaitu P3 (limbah sayur+limbah ikan) dengan massa yang cukup pada media pakan (Purnamasari dkk., 2018).

Konsumsi umur larva 26-35 hari konsumsi sebanyak 5,64 mg/ekor/hari. sampai larva 36-45 hari yang tertinggi Pada tahap ini umur membutuhkan nutrisi yaitu P2 (limbah ikan). Dalam tiga periode yang komples terdiri dari limbah ikan dan limbah sayur. Menurut Haryanto (2013), menyatakan limbah sayuran berfungsi sebagai sumber air bagi larva juga berfungsi sebagai sumber nutrisi usia P2 sangat tertinggi dibandingkan P1 dan P3 dikarenakan usia larva sangat membutuhkan banyak kandungan protein untuk mencukupi kebutuhan energi pertumbuhan karena akan melalui proses 
moulting (Haryanto,2013). Sementrara itu, konsumsi umur larva 46-55 hari yang tertinggi yaitu P3 (limbah sayur+limbah ikan) dengan massa konsumsi sebanyak 60,38 mg/ekor/hari. Pada P3 (limbah sayur+limbah ikan) merupakan rerata konsumsi yang tertinggi disetiap perlakuan maupun umur larva .

Pada umur 46-55 hari (larva tua) kebutuhan makan sangat banyak karena akan menuju ke fase pupa (tidak makan) sehingga mengalami peningkatan yang tajam. Perbedaan jumlah konsumsi dengan media limbah pada larva dikarenakan adanya faktor lain mempengaruhinya. Menurut Astuti (2017), Faktor eksternal lain adalah suhu dan kelembapan lingkungan sekitarnya. Dari hasil konsumsi larva Tenebrio molitor dapat dilihat hasil uji ANOVA two way taraf kepercayaan $5 \%$ menunjukkan bahwa adanya perbedaan signifikan pada jenis limbah organik, umur larva dan interaksi keduanya. Hal ini menunjukkan adanya keterkaitan antara jenis limbah organik terhadap umur larva. Kemampuan konsumsi pada tahapan larva akan meningkat dengan bertambahnya tingkatan umur dibandingkan umur awal. Hal ini disebabkan karena memasuki fase pupa yang membutuhkan pakan lebih banyak dibandingkan instar awal (Iding, 2020: 103).

Dari hasil uji ANOVA diketahui adanya interaksi yang signifikan yang harus dilanjutkan dengan melakukan uji lanjut duncan untuk melihat taraf perbedaan nyata dari setiap perlakuan. Maka diketahui perlakuan yang berbeda nyata adalah P1 (Limbah Sayur). Sedangkan perlakuan yang tidak berbeda nyata pada P2 (Limbah ikan) dan P3 (Limbah Sayur+ikan). Meskipun pada uji lanjut duncan menyatakan P2 (limbah ikan) adalah yang terbaik rerata konsumsi larva namun dari segi tingkat mortalitasnya memiliki persentase kematian mencapai $77 \%$ pada umur 46-55 hari. Sehingga dapat disimpulkan, P2 (limbah ikan) jika digunakan sebagai pakan konsumsi untuk peternak Tenebrio molitor menjadi tidak efektif di aplikasikan karena dapat mengalami kerugian. P3 (Limbah Sayur+ikan) juga memiliki rerata konsumsi yang tinggi setelah P2 (limbah ikan), tingkat mortalitasnya rendah hanya $47 \%$ hingga umur 46-55 hari. Dengan demikian, P3 (Limbah Sayur+ikan) yang dianggap terbaik untuk dikonsumsi larva dengan nutrisi yang kompleks dan tingkat mortalitasnya rendah. 


\section{Pertambahan berat tubuh Larva Tenebrio molitor}

Adapun hasil pertambahan berat tubuh Larva dapat dilihat pada tabel 2. Pertambahan berat tubuh Larva Tenebrio molitor sebagai berikut :

Tabel 2. Pertambahan berat tubuh Larva Tenebrio molitor

\begin{tabular}{lccccc}
\hline \multirow{2}{*}{ Pelakuan } & \multicolumn{4}{c}{ Umur (hari ke-) } & Rerata \pm SD \\
\cline { 2 - 5 } & $15-25$ & $26-35$ & $36-45$ & $46-55$ \\
\cline { 2 - 5 } & & \multicolumn{2}{c}{ mg/ekor/10 hari } \\
\hline P1 (Limbah sayur) & $6,00 \pm 3,58$ & $7,83 \pm 4,45$ & $30,83 \pm 10,44$ & $26,67 \pm 9,33$ & $17,83 \pm 13,29$ \\
\hline P2 (Limbah ikan) & $8,50 \pm 4,23$ & $8,67 \pm 4,32$ & $33,00 \pm 6,90$ & $29,00 \pm 11,08$ & $19,79 \pm 13,35$ \\
\hline P3 (Limbah sayur dan ikan) & $12,00 \pm 3,29$ & $12,33 \pm 5,47$ & $29,33 \pm 12,63$ & $31,33 \pm 8,36$ & $21,25 \pm 12,06$ \\
\hline
\end{tabular}

Berdasarkan penelitian

menunjukkan bahwa pertambahan bobot tubuh larva Tenebrio molitor pada umur larva 15-25 hari yang tertinggi P2 (Limbah ikan) dengan massa bobot tubuh mencapai $12 \mathrm{mg} / \mathrm{ekor} / 10$ hari. Hal ini diduga karena protein dan energi dari masing-masing media pakan perlakuan tersebut yang tinggi sehingga dapat memacu pertumbuhan dari larva Tenebrio molitor (Hartinininsih, 2014). Untuk umur larva 26-35 hari petumbuhan bobot tertinggi adalah P3 (larva memakan limbah sayur+ikan) dengan massa mencapai 12,33 mg/ekor/10hari. Umur 25-50 hari memasuki pertambahan bobot badan yang cukup cepat, maka membutuhkan pakan dengan kandungan energi yang lebih besar, akibatnya perlakuan P3 dengan campuran menunjukkan pertambahan bobot tubuh yang cepat dibandingkan perlakuan P1 dan P2 (Hartininingsih, 2014).

Untuk umur larva 36-45 hari pertumbuhan bobot tertinggi adalah P2 (limbah ikan) dengan massa bobot tubuh mencapai 33,00 mg/ekor/10hari berdampingan dengan jumlah konsumsi larva yang tinggi. Hal ini menunjukkan pada usia larva ini sangat membutuhkan banyak makanan untuk energi tubuhnya. Dimana, rerata pertambahan berat semakin bertambah sejalan dengan peningkatan tahapan instar dan peningkatan jumlah pakan yang dikonsumsi (Deasy, 2018).

Pada umur larva 46-55 hari tidak mengalami peningkatan yang sangat signifikan pada P3 sedangkan pada P1 dan P2 cenderung menurun. Hal ini diakibatkan larva yang memiliki umur 5060 hari merupakan umur menjelang tahap pupasi sehingga larva meningkatkan pakannya untuk mempersiapkan sediaan energi saat memupa dengan mengalami sedikit pertambahan berat bahkan pemendekan (Hutauruk, 2005). Untuk umur larva 46-55 hari pertumbuhan bobot tertinggi adalah P3 (limbah sayur+ikan) dengan massa bobot tubuh mencapai 31,33 
mg/ekor/10hari. Pada P3 merupakan konsumsi terbaik pada fase akhir atau memasuki prapupa untuk menyimpan energi larva. Menurut Rosadi (2001) dalam Hapsari menyatakan stadium makan merupakan makan hingga perkembangan dan kandungan pakan. Pakan kurang sesuai mengakibatkan siklus hidup menjadi lebih lama. Pada P3 memiliki nutrisi yang kompleks apabila dibandingkan P1 dan P2 sehingga siklus hidup larva menjadi lebih singkat.

Hasil penelitian berdasarkan pertambahan bobot tubuh larva menunjukkan bahwa perlakuan menggunakan limbah organik yang berbeda dengan usia larva memberikan tidak berpengaruh signifikan $(\mathrm{P}>0,05)$ pada interaksi perlakuan terhadap pertambahan bobot tubuh larva Tenebrio molitor. Pakan larva yang digunakan limbah yang hampir seragam seperti limbah sayur dan limbah ikan pada nutrisi yang sama pada larva pada setiap umur.

\section{KESIMPULAN}

Media pakan pada perlakuan P3 yang terdiri dari (campuran limbah ikan+limbah sayur) merupakan media pakan yang paling optimal terhadap konsumsi larva dengan rerata massa mencapai 28,91 mg/ekor/hari, pertambahan bobot tubuh larva dengan rerata massa mencapai 21,25 mg/ekor/10hari serta persentase mortalitas yang rendah hanya mencapai $47 \%$. Larva yang mempunyai konsumsi tertinggi adalah larva yang berumur 46-55 hari karena menuju ke fase pupa (tidak makan).

\section{SARAN}

Media pakan yang paling efektif untuk konsumsi larva Tenebrio molitor adalah P3 (limbah sayur+ikan). Namun dalam pemberian pakan limbah sayur perlu diperhatikan jenis sayur yang akan digunakan. Sebaiknya menggunakan sayur yang tidak terlalu banyak mengandung air.

\section{DAFTAR PUSTAKA}

Adawiyah, A.R. dan Selviastuti, R., 2014. Serburia Suplemen Tulang Ikan Bandeng dengan Cangkang Kapsul Alginat Untuk Mencegah Osteoporosis. Jurnal Ilmiah Mahasiswa, 4(1), pp. 53-59.

Astuti, F.K., Iskandar, A., \& Fitasari, E. 2017. Peningkatan Produksi Ulat Hongkong di Peternak Rakyat Desa Patihan, Blitar Melalui Teknologi Modifikasi Ruang Menggunakan Exhoust dan Termometer Digital Otomatis. Jurnal Akses Pengabdian Indonesia, 1 (2): 3948.

Azizah, A.N., Paranoto. Budiastuti MTH. 2019. Pemanfaatan Sampah Organik Sebagai Media Pakan Larva Tenebrio molitor (Ulat Hongkong). Prosiding Symbion (Symposium on Biology Education). e-ISSN: 2528-5726

Deasy, V.C.M. 2018. Kemampuan Berbagai Tingkatan Stadium Larva 
Kumbang Tenebrio molitor $L$. (Coleoptera:Tenebrionidae) Mengkonsumsi Styrofoam Dalam (Polystyrene). Jurnal Biologi Eksperimen Dan Keanekaragaman Hayati. 5 (1): 83-88.

Finke M, Winn D. 2004. Insects and related anthropods: A nutritional primer for rehabilitators. Journal of Wildlife Rehabilitation 14-17

Iding, Bakrie B., dan Wahyuningrum M. A. 2020. Pertambahan Bobot Badan Larva Ulat Hongkong (Tenebrio Molitor L.) dengan Penambahan Styrofoam Di Dalam Pakan. Jurnal Ilmiah Respati Vol. 11, No. 2 e-ISSN : 2622-9471

Hartiningsih, Eka F. S. 2014. Peningkatan Bobot Panen Ulat Hongkong Akibat Aplikasi Limbah Sayur dan Buah Pada Media Pakan Berbeda. Buana Sains Vol 14 No 1: 55-64

Hapsari, D.G.P.L., Fuah, A.M., \& Endrawati, $\quad$ Y.C. 2018. Produktivitas Ulat Hongkong (Tenebrio molitor) Pada Media Pakan yang Berbeda. Jurnal Ilmu Produksi dan Teknologi Hasil Peternakan, 6 (2): 53-59.

Hutauruk, S. M. 2005. Performans Ulat Tepung (Tenebrio molitor) yang Diberi Pakan Campuran Onggok Dan Konsentrat Selama Masa Pertumbuhan. Skripsi. Fakultas Pertenakan. Institut Pertanian Bogor, Bogor.
Kementrian Lingkungan Hidup. 2020. Pengelolaan sampah di Indonesia waste management. Jakarta : Badan Pusat Statistik/BPS-Statistics Indonesia

Purnamasari, D.K., Erwan, Syamsuhaidi, K.G.W., \& Nurmaya. 2018. Pertumbuhan dan Survival Rate Larva Tenebrio molitor yang Diberikan Media Pakan Berbeda. Jurnal Peternakan Sriwijaya, 7 (2): 17-23

Putra, S.V. 2013. Perkembangan Ovarium Burung Puyuh (Coturnix-coturnix japonica) yang Diberi Variasi Warna Lampu Pencahayaan Selama 16 Jam. Skripsi. Fakultas Matematika Dan Ilmu Pengetahuan Alam Universitas Negeri Semarang

Rosadi, A. 2001. Pengaruh komposisi beberapa jenis pakan terhadap siklus hidup dan daya produksi telur Cocyra cepholonica Stanton (Lepidoptera, Pyralidae). Skripsi. Institut Pertanian Bogor, Bogor.

Santoso dan. 2015. Pakan Alternatif Dari Limbah Sayuran Untuk Ikan Nila Hitam (Oreochromis niloticus). jurnal Ilmiah Perikanan dan Kelautan Vol. 7 No. 1

Tumando. S. Hanny W.M. Timbowo S.M. 2017. Kajian Mutu Ikan Cakalang Terhadap Nilai Kadar Air Dan Ph Selama Penyimpanan. Jurnal Media Teknologi Hasil Perikanan. Vol. 5 No. 2 Hal. 64-68 